\title{
Suplementasi Enkapsulasi Minyak Ikan Lemuru (Sardinella longiceps) Dalam Ransum Terhadap Performans Ayam Broiler
}

\author{
The effect of lemuru fish oil encapsulation on broiler performance \\ Tatik Suteky, Yosi Fenita, Yusnita \\ Jurusan Peternakan Fakultas Pertanian Universitas Bengkulu \\ Jalan Raya Kandang Limun Bengkulu, Telp. (0736) 21170 . Pst.219.
}

\begin{abstract}
Lemuru fish oil is a by product of lemuru fish oil industry. This oil can be used as a feed of poultry. However, the application of fish oil in feed ration has limitation because of their unstability against oxygen. Therefore, to avoid unstability encapsulation could be used to protect fish oil from oxidation processes. The purpose of this research was to evaluate the effect of encapsulation lemuru fish oil on performances of broiler, this research had been conducted two month started Agust $16^{\text {th }}$. until September $28^{\text {th }}$ 2005. The research was conducted in Laboratory of Animal Science, Faculty of Agriculture, University of Bengkulu. The research comprising of five treatments and four replications. The treatments were P0 (as control without lemuru fish oil), P1 ( $3 \%$ lemuru fish oil without encapsulation), P2 (2\% lemuru fish oil encapsulation), P3 (4\% lemuru fish oil encapsulation), P4 (6\% lemuru fish oil encapsulation). Parameters measured were feed consumption, body weight gain, feed convertion ratio and life weight. The result showed that the treatments did not give significant effect $(P>0.05)$ on feed consumption, body weight gain, feed convertion ratio and life weight. In conclution, using lemuru fish oil encapsulation $6 \%$ did not decrease of feed consumption, body weight gain, feed convertion ratio and life weight.
\end{abstract}

Key words : Fish oil (Sardinella longiceps), Encapsulation, Broiler

\begin{abstract}
ABSTRAK
Minyak dapat digunakan sebagai bahan pakan unggas. Namun penambahan minyak ke dalam pakan bisa mengakibatkan ransum mudah rusak karena mudah teroksidasi, sehingga pemanfaatan minyak kedalam pakan terbatas. Salah satu jenis minyak ikan adalah minyak ikan lemuru. Minyak ikan lemuru merupakan hasil pengolahan industri pengalengan dan penepungan ikan dengan harga yang murah. Untuk meningkatkan pemanfaatan minyak ikan lemuru dapat dilakukan metode enkapsulasi. Tujuan penelitian ini adalah untuk mengevaluasi pengaruh enkapsulasi minyak ikan lemuru (Sardinella longiceps) terhadap performans ayam broiler.Penelitian dimulai pada tanggal 16 Agustus 2005 sampai dengan 28 September 2005. Penelitian dilaksanakan di kandang peternakan Jurusan Peternakan Fakultas Pertanian Universitas Bengkulu. Penelitian in menggunakan 5 perlakuan 2 kontrol yaitu: P0: ransum tanpa penambahan minyak ikan, P1: ransum yang mengandung 3\% minyak ikan lemuru non enkapsulasi, P2: ransum basal ditambah 2\% enkapsulasi minyak ikan lemuru, P3: ransum basal ditambah 4\% enkapsulasi minyak ikan lemuru, P4: ransum basal ditambah $6 \%$ enkapsulasi minyak ikan lemuru. Variabel yang diamati; konsumsi ransum, pertambahan berat badan, konversi ransum dan berat badan akhir. Hasil analisis ragam menunjukkan bahwa perlakuan tidak berpengaruh nyata $(\mathrm{P}>0,05)$ terhadap konsumsi ransum, pertambahan berat badan, konversi ransum dan berat badan akhir. Hasil penelitian ini dapat disimpulkan bahwa pemberian enkapsulasi minyak ikan lemuru sampai taraf $6 \%$ tidak menurunkan konsumsi ransum, pertambahan berat badan, konversi ransum dan berat badan akhir.
\end{abstract}

Kata kunci : minyak ikan lemuru (Sardinella longiceps), Enkapsulasi, ayam Broiler

Jurnal Sain Peternakan Indonesia Vol. 1, No. 1,Januari - Juni 2006 


\section{PENDAHULUAN}

Minyak dapat digunakan sebagai bahan sumber energi pakan unggas. Suplementasi minyak dalam pakan merupakan suatu metode yang paling cocok untuk memenuhi kebutuhan energi yang tinggi pada pakan unggas.

Minyak yang bisa digunakan dalam pakan unggas, antara lain minyak nabati (minyak kelapa, minyak sawit, minyak jagung) dan minyak hewani (minyak ikan lemuru) masing-masing minyak mempunyai nilai energi yang berbeda tergantung susunan asam lemaknya.

Menurut Saerang (2003), penambahan minyak dalam ransum akan menguntungkan karena dapat meningkatkan zat gizi, menaikkan produksi telur dan berat telur. Hasil penelitian Saerang (1997) menunjukkan bahwa penambahan minyak ikan dalam ransum puyuh dapat meningkatkan produksi telur dan berat telur puyuh. Lebih lanjut dikemukakan puyuh yang diberi minyak ikan lemuru mempunyai rata-rata konsumsi pakan yang lebih rendah dibandingkan dengan puyuh yang diberi ransum dengan menggunakan minyak kelapa (Saerang, 2003).

Saragih (2005) menemukan bahwa pemberian minyak ikan lemuru 3\% yang diberi antioksidan bawang putih sampai taraf $0,6 \%$ tidak mempengaruhi konsumsi ransum, konversi ransum, berat telur dan produksi telur. Selanjutnya Terisia (2005) juga menemukan bahwa pemberian minyak ikan lemuru sebanyak 3\% dengan antioksidan kunyit sampai taraf $0,9 \%$ dapat memperbaiki konsumsi ransum serta tidak berpengaruh terhadap konversi ransum, berat telur, dan produksi telur.

Namun demikian penambahan minyak ke dalam pakan bisa mengakibatkan ransum mudah rusak karena mudah teroksidasi. Winarno (1997) menyatakan bahwa ketengikan diakibatkan oleh adanya peroksidan yang dapat mempercepat proses oksidasi. Fenita (2002) menambahkan bahwa bau amis pada produk akhir akibat pemberian minyak ikan menyebabkan pemanfaatan minyak dalam pakan terbatas. Selain itu juga berdasarkan sifat fisik dari minyak yang encer dan sulit tercampur didalam pakan mengakibatkan pemberian minyak secara teknis menjadi tidak efisien maka untuk meningkatkan pemanfaatan minyak ikan dapat dilakukan metode enkapsulasi.

Enkapsulasi yaitu proses untuk menyalut atau merangkap minyak ikan dengan suatu bahan penyalut dengan tujuan mengubah minyak ikan dari bentuk cair kebentuk padat (Fenita $d k k$., 2005). Tehnik enkapsulasi dapat mengatasi kelemahan minyak yang bersifat sangat sensitif terhadap oksigen dan memiliki cita rasa yang tidak enak dengan menghasikan produk padatan berukuran mikro sehingga dapat dengan mudah dicampur dengan makanan lain (Permadi $d k k$., 2002).

Berdasarkan hal tersebut perlu dilakukan pemanfaatan teknologi enkapsulasi terhadap minyak ikan yang kaya akan omega3 (EPA dan DHA) dengan menggunakan bahan penyalut pollard untuk melihat performans ayam broiler.

Penelitian ini bertujuan untuk mengevaluasi pengaruh enkapsulasi minyak ikan lemuru (Sardinella longiceps) terhadap performans ayam broiler. Hipotesis penelitian ini adalah diharapkan dengan pemberian enkapsulasi minyak ikan lemuru (Sardinella longiceps) dalam ransum dapat meningkatkan performans ayam broiler.

\section{MATERI DAN METODE}

\section{Waktu dan Tempat Penelitian}

Penelitian ini dilakukan selama 6 minggu yaitu mulai tanggal 16 Agustus 2005 sampai tanggal 28 September 2005 , penelitian ini dilakukan di Laboratorium Lapangan Jurusan Peternakan Universitas Bengkulu.

\section{Bahan dan Alat}

Bahan yang dibutuhkan 100 ekor DOC, bahan pakan yang digunakan: jagung kuning, dedak halus, tepung ikan, bungkil kedelai, minyak ikan lemuru, gelatin, twenn-80, dengan bahan penyalut yaitu, pollard. enkapsulasi minyak ikan lemuru. Sedangkan alat yang digunakan dalam penelitian ini adalah tempat pakan, tempat minum, timbangan Analitik Merk Ohaus 2000 gram, alat tulis, dan kandang litter. 


\section{Rancangan Percobaan}

Rancangan yang digunakan dalam penelitian ini adalah rancangan acak lengkap (RAL) dengan 5 perlakuan. Setiap perlakuan terdiri dari 4 ulangan dan setiap ulangan terdiri dari 5 ekor broiler, sehingga broiler yang dibutuhkan 100 ekor. Masing-masing perlakuan tersebut adalah :

P0 : ransum tanpa minyak ikan (kontrol)

$\mathrm{Pl}$ : ransum yang mengandung $3 \%$ minyak ikan lemuru non enkapsulasi

P2 : ransum basal $+2 \%$ enkapsulasi minyak ikan

P3 : ransum basal $+4 \%$ enkapsulasi minyak ikan

P4 : ransum basal $+6 \%$ enkapsulasi minyak ikan

Data yang diperoleh dianalisis dengan sidik ragam (ANOVA), dengan menggunakan program SPSS 10 for Windows bila terdapat pengaruh yang nyata, dilanjutkan dengan uji Duncan's Multiple Range Test (Steel dan Torrie, 1991)

\section{Tahapan Penelitian}

Penyediaan enkapsulasi minyak ikan lemuru

Bahan utama yang digunakan adalah minyak ikan lemuru yang didapatkan dari PT. Bali Manyu Permai Desa Nagari Bali dan sebagai bahan penyalut pollard, gelatin dan tween-80. Adapun pembuatan enkapsulasi adalah sebagai berikut: bahan penyalut pollard sebanyak $75 \%$ dan gelatin $25 \%$ dicampur dan diaduk sampai rata, setelah itu masukkan minyak ikan sebanyak $25 \%$ diaduk sampai homogen, kemudian ditambahkan tween-80 sebanyak $10 \%$ dari minyak ikan kemudian diaduk kembali sampai homogen, setelah itu dikeringkan dengan hair dryer selama 15 menit.

\section{Persiapan kandang}

Kandang dibuat dengan ukuran $75 \mathrm{~cm} x$ $75 \mathrm{~cm} \times 75 \mathrm{~cm}$ sebanyak 20 petak, dinding terbuat dari bambu, lantai dengan alas litter, atap terbuat dari seng. Kandang dibersihkan kemudian disanitasi dengan menggunakan formalin $1 \%$.

\section{Penyusunan ransum penelitian}

Ransum percobaan disusun berdasarkan imbangan protein berkisar antara 20-21\% dan energi 3000-3200 $\mathrm{kkal} / \mathrm{kg}$ (Wahyu, 1992). Sumber minyak yang digunakan berbeda; untuk perlakuan kontrol menggunakan minyak bimoli dan minyak ikan lemuru tanpa enkapsulasi sedangkan enkapsulasi minyak ikan lemuru digunakan dengan level 2\%,4\% dan $6 \%$

\section{Variabel yang Diamati}

\section{Konsumsi Ransum}

Konsumsi ransum dihitung berdasarkan jumlah ransum yang disediakan setiap awal minggu kemudian dikurangi dengan sisa ransum pada akhir minggu.

\section{Pertambahan Berat Badan}

Pertambahan berat badan dihitung dengan menghitung selisih antara berat badan pada minggu tersebut dengan berat badan minggu sebelumnya

\section{Konversi Ransum}

Konversi ransum dihitung berdasarkan perbandingan antara konsumsi ransum tiap minggu dengan pertambahan berat badan dalam satuan waktu sama.

\section{Berat Badan Akhir}

Berat badan akhir dihitung dengan

menimbang berat badan pada minggu terakhir perlakuan

\section{HASIL DAN PEMBAHASAN}

\section{Konsumsi Ransum}

Hasil analisis ragam pada Tabel 3 menunjukkan bahwa perlakuan berpengaruh tidak nyata $(\mathrm{P}>0,05)$ terhadap konsumsi ransum ayam. Rata-rata konsumsi ransum selama penelitian berturut-turut ( $\mathrm{P} 0)$ 455,97(g/ek/mgg),(P!)452,13(g/ek/mgg), (P2)437,37(g/ek/mgg),(P3)439,52(g/ek/mgg), P4)471,72(g/ek/mgg). Dilihat dari rataannya menunjukkan bahwa konsumsi tertinggi terdapat pada perlakuan P4 (ransum dengan penambahan enkapsulasi minyak ikan lemuru $6 \%$ ) sedangkan konsumsi terendah pada perlakuan P2 (ransum dengan penambahan enkapsulasi minyak ikan lemuru 2\%) 
Tabel 1. Kandungan nutrisi penyusun ransum

\begin{tabular}{|c|c|c|c|c|c|c|}
\hline Bahan pakan & Protein (\%) & $\begin{array}{c}\text { Energi } \\
(\mathrm{kkal} / \mathrm{kg})\end{array}$ & SK $(\%)$ & $\mathrm{Ca}(\%)$ & $P(\%)$ & Lemak $(\%)$ \\
\hline Jagung* & 9.27 & 3340 & 2,82 & 0,06 & 0,29 & 3,9 \\
\hline Dedak * & 13,81 & 1630 & 5,49 & 0,1 & 1,94 & 4,85 \\
\hline Tepung ikan* & 58,88 & 2728 & 3,15 & 3,1 & 2,15 & 8,14 \\
\hline Bungkil kedelai* & 40,55 & 2843 & 5,65 & 0,21 & 0,11 & 1,92 \\
\hline Mineral suplemen** & 0 & 0 & 0 & 32,5 & 10 & 0 \\
\hline Minyak bimoli*** & 0 & 9000 & 0 & 0 & 0 & 99 \\
\hline Minyak ikan lemuru* & 0 & 8450 & 0 & 0 & 0 & 84 \\
\hline Enkapsulisasi ${ }^{* * *}$ & 14,87 & 5273 & 0 & 0 & 0 & 22,43 \\
\hline
\end{tabular}

Tabel 2. Komposisi bahan penyusun ransum dan kandungan nutrisi ransum perlakuan.

\begin{tabular}{|c|c|c|c|c|c|}
\hline Bahan pakan & $\begin{array}{c}\text { P0 } \\
\text { (kontrol) }\end{array}$ & $\mathrm{P} 1$ & P2 & P3 & $\mathrm{P}^{3} 4$ \\
\hline Jagung (\%) & 57 & 57 & 60 & 56 & 54 \\
\hline Dedak $(\%)$ & 10 & 10 & 8 & 10 & 10 \\
\hline Tepung ikan (\%) & 14 & 14 & 14 & 14 & 14 \\
\hline Bungkil kedelai (\%) & 14 & 14 & 14 & 14 & 14 \\
\hline Mineral suplemen (\%) & 2 & 2 & 2 & 2 & 2 \\
\hline Minyak bimoli (\%) & 3 & 0 & 0 & 0 & 0 \\
\hline Minyak ikan lemuru (\%) & 0 & 3 & 0 & 0 & 0 \\
\hline Enkapsulasi (\%) & 0 & 0 & 2 & 4 & 6 \\
\hline Total & 100 & 100 & 100 & 100 & 100 \\
\hline Protein $(\%)$ & 20,58 & 20,58 & 20,88 & 21,08 & 21,19 \\
\hline Energi ( kkal/kg) & 3116,74 & 3098,74 & 3019,80 & 3024,26 & 3062.92 \\
\hline Serat kasar $(\%)$ & 2,63 & 2,63 & 2.60 & 2.59 & 2.54 \\
\hline Kalsium (\%) & 1,53 & 1.53 & 1,25 & 1.25 & 1,25 \\
\hline Phospor (\%) & 1,13 & 1,13 & 1,09 & 1,13 & 1,12 \\
\hline Lemak (\%) & 7,64 & 7,19 & 5,04 & 5,53 & 5,90 \\
\hline
\end{tabular}

Dari tabel 3 juga dapat dilihat bahwa semakin tinggi level enkapsulasi yang diberikan maka terjadi peningkatan konsumsi ransum. Peningkatan ini diduga karena proses enkapsulasi dapat menghilangkan bau amis pada minyak ikan lemuru. Menurut Wahyu (1992) ternak unggas memiliki alat pengecap (perasa) yang sangat sensitif terhadap perubahan rasa dan bau pada pakan, yang didukung oleh pendapat Fenita dkk. (2005) menyatakan bahwa tehnik enkapsulasi bertujuan untuk melindungi kandungan yang terdapat dalam minyak ikan lemuru yaitu asam lemak omega-3 berupa EPA dan DHA

Pertambahan Berat Badan

Pertambahan berat badan ayam yang diberi minyak ikan lemuru dalam ransum dapat dilihat pada Tabel 4 .

Tabel 3. Rataan konsumsi ransum

\begin{tabular}{ccccccc}
\hline Ulangan & \multicolumn{7}{c}{ Perlakuan } & Ket \\
\cline { 2 - 6 } & P0 & P1 & P2 & P3 & P4 & \\
\hline U1 & 441,73 & 440,00 & 419,03 & 461,73 & 499.87 & \\
U2 & 438,33 & 492,87 & 454,70 & 450,20 & 486.37 \\
U3 & 510,63 & 453,57 & 435,87 & 369,37 & 385.30 & \\
U4 & 433,17 & 422,10 & 439,87 & 476,77 & 515,33 & \\
\hline Rataan & 455,97 & 452,13 & 437,37 & 439,52 & 471,72 & ns \\
\hline Sd & 30,05 & 14,66 & 48,01 & 58,81 & 14,46 & ns \\
\hline
\end{tabular}

Keterangan: $\mathrm{ns}$ : berpengaruh tidak nyata $(\mathrm{P}>0,05)$, $\mathrm{P} 0$ : Ransum dengan minyak bimoli $3 \%, \mathrm{Pl}:$ Ransum dengan minyak ikan lemuru 3\%, P2: Ransum dengan enkapsulasi minyak ikan lemuru 2\%, P3: Ransum dengan enkapsulasi minyak ikan lemuru 4\%, P4 :Ransum dengan enkapsulasi minyak ikan lemuru $6 \%$ 
Hasil analisis ragam menunjukkan bahwa perlakuan tidak berpengaruh nyata $(\mathrm{P}>0,05)$ terhadap pertambahan berat badan. Rata-rata pertambahan berat badan berturut-turut (PO) 194,28 $\mathrm{gr} / \mathrm{ek} / \mathrm{mgg}$. (P1) 206,63 gr/ek/mgg, (P2) 196,07 $\mathrm{gr} / \mathrm{ek} / \mathrm{mgg}$ (P3) 192,51 gr/ekor/mgg (P4) $227,89 \mathrm{gr} / \mathrm{ek} / \mathrm{mgg}$

Tabel. 4 Rataan pertambahan berat badan

\begin{tabular}{|c|c|c|c|c|c|c|}
\hline \multirow[t]{2}{*}{ Ulangan } & \multicolumn{5}{|c|}{ Perlakuan } & \multirow[t]{2}{*}{ Ket } \\
\hline & $\mathrm{P} 0$ & $\mathrm{Pl}$ & P2 & P3 & $\mathrm{P} 4$ & \\
\hline \multicolumn{7}{|c|}{$\ldots \ldots \ldots$ g/ekor/minggu ........ } \\
\hline U1 & 213,30 & 182,63 & 208,33 & 199,57 & 231,70 & \\
\hline U2 & 173,98 & 226,83 & 173,70 & 176,30 & 203,13 & \\
\hline U3 & 197,93 & 220,83 & 193,18 & 192,17 & 247,01 & \\
\hline U4 & 191,90 & 196,22 & 209,06 & 202,00 & 229.73 & \\
\hline Rataan & 194,28 & 206,63 & 196,07 & 192,51 & 227,89 & \\
\hline $\mathrm{Sd}$ & 16,26 & 20,77 & 16,61 & 11,59 & 18.22 & ns \\
\hline
\end{tabular}

Keterangan: ns : berpengaruh tidak nyata $(\mathrm{P}>0,05), \mathrm{P} 0$ : Ransum dengan minyak bimoli $3 \%$. P 1 : Ransum dengan minyak ikan lemuru 3\%, P2 : Ransum dengan enkapsulasi minyak ikan lemuru 2\%, P3: Ransum dengan enkapsulasi minyak ikan lemuru 4\%, P4 : Ransum dengan enkapsulasi minyak ikan lemuru 6\%

Tabel 4 juga dapat dilihat bahwa dengan penambahan minyak bimoli sebesar 3\% (P0) pertambahan berat badannya lebih rendah bila dibandingkan dengan perlakuan menggunakan penambahan minyak ikan lemuru sebesar 3\% (P1) sedangkan perlakuan yang menggunakan enkapsulasi minyak ikan lemuru sebesar $2 \%$ (P2) dan 4\% (P3) pertambahan berat badannya lebih rendah dibandingkan dengan P4 yang diberi enkapsulisasi minyak ikan lemuru sebesar $6 \%$.

Dengan demikian perlakuan dengan pertambahan berat badannya tertinggi adalah P4. Pertambahan berat badan ini diduga karena ransum yang diberikan tidak berbau amis, karena minyak ikan lemuru sudah dienkapsulasi. Menurut Permadi $d k k$. (2002) teknik enkapsulasi dapat mengatasi kelemahan minyak ikan yang bersifat sangat sensistif terhadap oksigen dan memiliki cita rasa yang tidak enak dengan menghasilkan produk padatan berukuran mikro sehingga dapat dengan mudah dicampur dengan makanan lain Hal tersebut diatas didukung dengan pendapat Fenita $(2002 ; 2003)$ dan Fenita $d k k$. (2005) yang menyatakan bahwa bau amis dari minyak ikan menyebabkan pemanfaatannya terbatas dalam ransum dan juga mempengaruhi produk akhir dari ternak yang mengkonsumsinya, dimana daging yang dihasilkan masih terasa amisnya

\section{Konversi Ransum}

Konversi ransum ayam selama penelitian dapat dilihat pada Tabel 5 .

Tabel 5. Rataan konversi ransum

\begin{tabular}{ccccccc}
\hline Ulangan & \multicolumn{5}{c}{ Perlakuan } & Ket \\
\hline & P0 & P1 & P2 & P3 & P4 & \\
\hline U1 & 2,52 & 2,64 & 2,23 & 2,29 & 2,20 & \\
U2 & 2,59 & 2,24 & 2,64 & 2,79 & 2,40 & \\
U3 & 2,60 & 2,11 & 2,49 & 2,27 & 1,72 & \\
U4 & 2,36 & 2,32 & 2,18 & 2,34 & 2,25 & \\
\hline Rataan & 2,52 & 2,33 & 2,38 & 2,42 & 2,14 & ns
\end{tabular}

Keterangan: $\mathrm{ns}$ : berpengaruh tidak nyata $(\mathrm{P}>0,05)$, $\mathrm{P} 0:$ Ransum dengan minyak bimoli $3 \%$, $\mathrm{Pl}:$ Ransum dengan minyak ikan lemuru 3\%, P2 : Ransum dengan enkapsulasi minyak ikan lemuru 2\%, P3: Ransum dengan enkapsulasi minyak ikan lemuru 4\%, P4 : Ransum dengan enkapsulasi minyak ikan lemuru $6 \%$

Hasil analisis ragam menunjukkan bahwa terhadap konversi ransum. Nilai konversi P0 perlakuan berpengaruh tidak nyata $(\mathrm{P}>0,05)$ lebih tinggi dari P1, P2, P3 dan P4. Konversi Jurnal Sain Peternakan Indonesia Vol. 1, No. 1, Januari - Juni 2006 
yang tertinggi yaitu pada P0 sebesar 2,52 , hal ini disebabkan oleh tingginya konsumsi ransum yang tidak diimbangi dengan pertambahan berat badan, sedangkan konversi terendah yaitu pada perlakuan $\mathrm{P} 4$ sebesar 2,14. Menurut Anggorodi (1985), semakin kecil angka konversi ransum maka semakin baik bila ditinjau dari segi ekonomi.

Dari Tabel 5. juga dapat dilihat bahwa pemberian enkapsulasi minyak ikan lemuru memiliki nilai konversi ransum yang lebih rendah dari perlakuan kontrol (P0). Menurut Koeshardini dan Dewiki (2003) nilai konversi pakan yang semakin kecil, berarti semakin efisien ayam dalam mengkonsumsi pakan untuk meningkatkan bobot badannya.

Hal diatas juga didukung oleh penelitian Farrel (1995) disitasi oleh Saerang (2003) yang menyatakan bahwa penambahan omega3 pada ransum ayam memberikan hasi konsumsi ransum nyata lebih rendah dan produksi telur nyata lebih tinggi, dengan berat telur yang tidak berbeda nyata

\section{Berat Badan ayam umur 6 minggu}

Berat badan akhir ayam selama 6 minggu penelitian dapat dilihat pada Tabel 6

Tabel. 6 Rataan berat badan akhir

\begin{tabular}{|c|c|c|c|c|c|c|}
\hline \multirow{2}{*}{ Ulangan } & \multicolumn{5}{|c|}{ Perlakuan } & \multirow{2}{*}{ Ket } \\
\hline & $\mathrm{PO}$ & $\mathrm{P} 1$ & $\mathrm{P} 2$ & P3 & P4 & \\
\hline \multicolumn{7}{|c|}{$\ldots \ldots \ldots$ gr/ek/mgg ........ } \\
\hline U1 & 1351,00 & 1176,00 & 1327,00 & 1269.00 & 1456,00 & \\
\hline U2 & 1119,50 & 1430,80 & 1126,60 & 1132.00 & 1294,40 & \\
\hline U3 & 1501,00 & 1399,00 & 1229,25 & 1226,00 & 1551,67 & \\
\hline U4 & 1223,40 & 1251,50 & 1326,75 & $1290.60)$ & 1452,00 & \\
\hline Rataan & 1298,73 & 1314,38 & 1252,50 & 1229.40 & 1438,57 & ns \\
\hline sd & 164,77 & 120,78 & 95,77 & 70.27 & 106,56 & \\
\hline
\end{tabular}

Keterangan: ns: berpengaruh tidak nyata $(\mathrm{P}>0,05), \mathrm{P} 0=$ Ransum dengan minyak bimoli $3 \%$, P1 $=\mathrm{Ransum}$ dengan minyak ikan lemuru 3\%, P2 = Ransum dengan enkapsulasi minyak ikan lemuru 2\%, P3= Ransum dengan enkapsulasi minyak ikan lemuru 4\%, P4 = Ransum dengan enkipsulasi minyak ikan lemuru $6 \%$

Hasil analisis ragam menunjukkan bahwa perlakuan berpengaruh tidak nyata $(\mathrm{P}>0,05)$ terhadap berat badan akhir. Berat badan akhir yang tertinggi yaitu pada perlakuan P4 sebesar 1438,57 g sedangkan yang terendah yaitu perlakuan P3 sebesar $1229,40 \mathrm{~g}$. Berat badan ayam tertinggi pada perlakuan P4 diduga pada perlakuan ini merupakan level optimum dari penggunaan enkapsulasi minyak ikan lemuru dalam ransum. Menurut Anggorodi (1985) bahwa konsumsi ransum dipengaruhi oleh beberapa faktor antara lain genetik, jenis kelamin, umur, lingkungan, kesehatan ternak, imbangan zatzat makanan, kecepatan pertumbuhan, besar produksi, tingkat energi ransum, kualitas dan palatabilitas ransum.

Koeshardini dan Dewiki (2003), mengemukakan hal yang hampir sama yaitu jumlah pakan yang dikonsumsi tergantung pada sifat berat badan yang diwarisi dan nilai gizi pakan

\section{SIMPULAN}

Hasil penelitian ini dapat ditarik kesimpulan bahwa suplementasi enkapsulasi minyak ikan lemuru kedalam pakan sampai level $6 \%$ tidak menurunkan konsumsi ransum, konversi ransum, pertambahan berat badan dan berat badan akhir.

\section{DAFTAR PUST AKA}

Anggorodi, R. 1985. Kemajuan Mutakhir Dalam Ilmu Makanan Ternak Unggas. Universitas Indonesia Press, Jakarta.

Ditjen Perikanan. 1999. Statistik Perikanan Indonesia. Direktorat Jendral Perikanan. Departemen Pertanian, Jakarta.

Fenita, Y. 2002. Suplementasi lisin dan metionin serta minyak ikan lemuru ke dalam ransum berbasis hidrolisat bulu ayam terhadap perlemakan dan perturnbuhan ayam ras pedaging. Disertasi. Institut Pertanian Bogor, Bogor. 
Fenita,Y. 2003. Pengaruh prekursor karnitin dan minyak ikan lemuru dalam ransum berbasis hidrolisis bulu ayam terhadap kolesterol serum darah broiler. Jurnal Pengembangan Peternakan Tropis Universitas Diponegoro special edition. 26-29.

Fenita. Y, Irma B dan Erpina T. 2005. Uji kerusakan lemak ransum ayam petelur yang menggunakan minyak ikan lemuru (Sardinella longiceps) dengan penambahan bawang putih sebagai antioksidan alami selama penyimpanan. Jurnal Ilmiah Ilmu-ilmu Peternakan. 8 (4) $45-48$.

Koeshardini. S. Y. P, Dewiki. S. 2003. Performa Ayam Merawang yang Dipelihara Intensif Didaerah Bogor.http: Pk.Ut.Ac.Id/Jmst/Jurnal_2003.2/Jurnal htm.12 April 2006.

NRC, 1994. Nutrient Requirement of Poultry. Ninth Revised Edition. National Academy Press Washington, D.C.

Permadi, D. Suwardjo, H. A. Rasyid, N. Djazuli, dan Y. A. B. Jatmiko. 2002. Stabilitas Emulsi dan Efisiensi Enkapsulasi Minyak Ikan Lemuru (Sardinela longiceps). http: // rudyct. Com /sem 1_023/group b_ 123. htm. 24 April 2005.

Saerang, J. L. P. 1997. Pengaruh Minyak Nabati dan Lemak Hewani Dalam Ransum Puyuh Petelur Terhadap Performans, Daya Tetas, Kadar Kolesterol Telur, dan Plasma Darah. Pasca sarjana UGM, Yogyakarta.
Saerang, J. 2003. Efek Pakan dengan Penambahan Berbagai Minyak terhadap Produksi dan Kualitas Telur. http//rudyct tripod. com/pps 702 7/043/pinky- Saerang atm. 21 Mei 2004.

Saragih, H. 2005. Suplementasi bawang putih sebagai anti oksidan dalam ransum berbasis minyak ikan lemuru (Sardinella longiceps) terhadap performans produksi ayam petelur. Skripsi Fakultas Pertanian UNIB. Bengkulu. (tidak dipublikasikan)

Steel, R.G.D. and J.H. Torrie. 1991. Principles and Procedure of Statistics. Diterjemahkun oleh B. Sumantri. 1993. Prinsip dan Prosedur Statistika "Suatu Pendeskatan Biometrik". PT. Gramedia Pustaka Utama. Jakarta.

Terisia, H. 2005. Pemberian kunyit (Curcuma domestica) dalam ransum berbasis minyak ikan lemuru (Sardinella longiceps) terhadap performans produksi ayam petelur. Skripsi Fakultas Pertanian UNIB. Bengkulu. (tidak dipublikasikan).

Untung, O., S.P. Peni, I.R. Enny. 1991. Minyak Limbah Ikan Lemuru, Menurunkan Kolesterol. Agribisnis 38 (4) : 20-24, 1991.

Wahyu, J. 1992. Ilmu Nutrisi Unggas. Gadjah Mada University Press, Yogyakarta.

Winarno, F. G. 1997. Kimia Pangan dan Gizi. Edisi Kedelapan. PT. Gramedia Pustaka Utama, Jakarta. 